\title{
Sciatic nerve-conditioned medium with the addition of Croton blanchetianus Baill essential oil promotes morphological plasticity in spinal cord cultured cells
}

\author{
Meio condicionado de nervo ciático com a adição de óleo essencial de Croton blanchetianus Baill \\ promove plasticidade morfológica em cultura de células de medula espinal \\ El medio acondicionado del el nervio ciático con la adición de aceite esencial de Croton \\ blanchetianus Baill promueve la plasticidad morfológica en las células cultivadas de la médula \\ espinal
}

Luciana Cristina Borges Fernandes ORCID: https://orcid.org/0000-0001-6920-2645

Federal Rural Semi Arid University, Brazil E-mail: lucianacbf@hotmail.com

Salvador Viana Gomes Junior

ORCID: https://orcid.org/0000-0002-5173-8318 University of the State of Rio Grande do Norte, Brazil E-mail: salvajunior@live.com

Ianara Mendonça Costa

ORCID: https://orcid.org/0000-0001-7568-0248 University of the State of Rio Grande do Norte, Brazil E-mail: ianara.nutricao@gmail.com

Francisca Idalina Neta

ORCID: https://orcid.org/0000-0003-2851-3062 University of the State of Rio Grande do Norte, Brazil E-mail: neta.nutri@hotmail.com

Rodrigo Freire Oliveira

ORCID: https://orcid.org/0000-0003-1685-3107 University of the State of Rio Grande do Norte, Brazil E-mail: rodrigo_cds12@hotmail.com

Lucídio Clebeson de Oliveira

ORCID: https://orcid.org/0000-0002-2033-7546 University of the State of Rio Grande do Norte, Brazil

E-mail: lucidioclebeson@hotmail.com

Eduardo Pereira de Azevedo

ORCID: https://orcid.org/0000-0002-8630-6240 Potiguar University (UnP), Brazil E-mail: eduardo.azevedo@unp.br

Francisco Fábio Mesquita Oliveira

ORCID: https://orcid.org/0000-0001-8191-1532 University of the State of Rio Grande do Norte, Brazil

E-mail: ffabiomesquita@gmail.com

Cynthia Cavalcanti de Albuquerque

ORCID: https://orcid.org/0000-0002-0959-1404

University of the State of Rio Grande do Norte, Brazil

E-mail: cynthiacavalcanti@uern.br

Francisco Felipe Maia da Silva

ORCID: https://orcid.org/0000-0001-6794-109X Federal Institute of Education, Science and Technology of the State of Rio Grande do Norte, Brazil E-mail: felipe.maia@ifrn.edu.br Jael Soares Batista

ORCID: https://orcid.org/0000-0001-9663-7468 Federal Rural Semi Arid University, Brazil E-mail: jaelsoares@hotmail.com

José Rodolfo Lopes de Paiva Cavalcanti

ORCID: https://orcid.org/0000-0002-1554-3249 University of the State of Rio Grande do Norte, Brazil

E-mail: joserodolfolopes@uol.com.br

Carlos Iberê Alves Freitas

ORCID: https://orcid.org/0000-0003-0859-3528

Federal Rural Semi Arid University, Brazil 


\author{
E-mail: iberefreitas@bol.com.br \\ Fausto Pierdoná Guzen \\ ORCID: https://orcid.org/0000-0002-5458-7236 \\ University of the State of Rio Grande do Norte, Brazil \\ E-mail: faustoguzen@uern.br
}

\begin{abstract}
Spinal cord injury is a devastating condition that leads to significant disabilities. The treatment for this problem is a challenge in neuroscience, and it is necessary to combine different strategies to obtain functional recovery outcomes. There are many herbal natural products, such as Croton blanchetianus Baill (CB) essential oil, a Brazilian semi-arid bush with neuroprotective substances tested in regeneration processes and synaptic plasticity. Thus, this study analyzed the cellular plasticity of spinal cord neurons and glial cells in the presence of sciatic nerve-conditioned medium (SNCM) before the addition of CB essential oil. Cell morphology was assessed over 96 hours, and immunocytochemistry analyses were conducted for GFAP, GAP-43 and NeuN. Photomicrographs were made by scanning electron microscopy (SEM). Morphological analysis showed evident trophic development in the groups that received $\mathrm{CB}$ essential oil ( $\mathrm{P}>0.000)$, immunoreactivity for GFAP, GAP-43 and NeuN and the plasticity of these cells were confirmed by SEM. This pioneer study about the plasticity of spinal cord neurons and glial cells opens new possibilities and techniques with essential oils for cell therapy in the presence of SNCM, which promoted neuroprotective action.
\end{abstract}

Keywords: Essential oil; Sciatic nerve; Trophism; Neuroprotection.

\title{
Resumo
}

A lesão da medula espinhal é uma condição devastadora que leva a deficiências significativas. O tratamento desse problema é um desafio da neurociência, sendo necessário combinar diferentes estratégias para obter resultados de recuperação funcional. Muitos são os produtos naturais à base de plantas, como o óleo essencial de Croton blanchetianus Baill (CB), um arbusto do semiárido brasileiro com substâncias neuroprotetoras testadas em processos de regeneração e plasticidade sináptica. Assim, este estudo analisou a plasticidade celular dos neurônios da medula espinhal e células da glia na presença de meio condicionado de nervo ciático (SNCM) antes da adição do óleo essencial de CB. A morfologia celular foi avaliada ao longo de 96 horas e as análises de imunocitoquímica foram conduzidas para GFAP, GAP-43 e NeuN. As fotomicrografias foram feitas por microscopia eletrônica de varredura (SEM). A análise morfológica mostrou evidente desenvolvimento trófico nos grupos que receberam óleo essencial de CB (P> 0,000), imunorreatividade para GFAP, GAP-43 e NeuN e a plasticidade dessas células foi confirmada por SEM. Esse estudo pioneiro sobre a plasticidade dos neurônios da medula espinhal e das células gliais abre novas possibilidades e técnicas com óleos essenciais para terapia celular na presença de SNCM, que promoveu ação neuroprotetora.

Palavras-chave: Óleo essencial; Nervo ciático; Trofismo; Neuroproteção.

\section{Resumen}

La lesión de la médula espinal es una condición devastadora que conduce a discapacidades importantes. El tratamiento de este problema es un desafío para la neurociencia, y es necesario combinar diferentes estrategias para obtener resultados de recuperación funcional. Hay muchos productos herbales naturales, como el aceite esencial de Croton blanchetianus Baill (CB), un arbusto del semiárido brasileño con sustancias neuroprotectoras probadas en procesos de regeneración y plasticidad sináptica. Por lo tanto, este estudio analizó la plasticidad celular de las neuronas de la médula espinal y las células gliales en presencia de medio del nervio ciático acondicionado (SNCM) antes de la adición del aceite esencial CB. Se evaluó la morfología celular durante 96 horas y se realizaron análisis de inmunocitoquímica para GFAP, GAP-43 y NeuN. Las fotomicrografías se realizaron mediante microscopía electrónica de barrido (SEM). El análisis morfológico mostró un evidente desarrollo trófico en los grupos que recibieron aceite esencial $\mathrm{CB}(\mathrm{P}>0,000)$, inmunorreactividad para GFAP, GAP-43 y NeuN y la plasticidad de estas células fue confirmada por SEM. Este estudio pionero sobre la plasticidad de las neuronas en la médula espinal y las células gliales abre nuevas posibilidades y técnicas con aceites esenciales para terapia celular en presencia de SNCM, que promovió la acción neuroprotectora.

Palabras clave: Aceite essencial; Nervio ciático; Trofismo; Neuroprotección.

\section{Introduction}

Spinal cord injury (SCI) is defined as a central nervous system injury that results in a large functional deficit. It is a devastating condition that leads to significant disabilities because patients with SCI develop many complications and multiple organ dysfunctions (Chariker et al., 2019).

In veterinary practice, SCI often culminates in euthanasia of the affected animal, and therefore physical and emotional 
stress on owners (Bergman, 2000; Dumont et al., 2001). In addition to primary mechanical trauma to the spinal cord (SC) axons, there is rupture of blood vessels and cell membrane, resulting in a cascade process leading to a progressive secondary injury which can lead to edema, ischemia, inflammation, and cytokine production. Consequently, oxidative stress and glial scarring cause irreversible tissue necrosis and neuronal death (Huang et al., 2007; Lin et al., 2011; Ormond et al., 2014).

For this reason, when investigating therapeutic strategies, it is imperative to explore interventions that minimize these effects and promote morphological and functional recovery (Marcos et al., 2016; Souza et al., 2010). The major negative effect on cells by the secondary lesion of SCI, is the release of free radicals that attack the cell membrane and this mechanism, in turn, modify cell components such as unsaturated fatty acids by lipid peroxidation process (Cemil et al., 2010; Huang et al., 2007).

SC treatment after the injury is a challenge for neuroscience, considering that recent studies show that the combination of different strategies is necessary to obtain functional recuperation results (Houle et al., 2013). Therefore, the search for new alternatives and research in regeneration is important (Mothe \& Tator, 2012; Ren \& Young, 2013; Varma et al., 2013).

Different therapeutic modalities have been suggested to avoid changes leading to neuronal death, in the neonatal or adult phase. Neuroprotection is defined as any strategy and mechanism that protects the central nervous system (CNS) from neuronal injury. Thus, there are currently numerous natural plant-derived products that have been reported as neuroprotective in traditional medicine (Elufioye et al., 2010).

Many studies indicate the efficiency of essential oils in reducing pain, anxiety and stress symptoms in animal models and humans alike, with different CNS disorders (Lee et al., 2011; Tankam \& Ito, 2013). They are substances derived from secondary metabolism and present considerable complexity with hundreds of organic compounds, such as monoterpenes, sesquiterpenes and phenylpropanoids, which confer their organoleptic characteristics (Barbosa et al., 2016; Bizzo et al., 2009; Souza et al., 2010). The family Euphorbiaceae has in the genus Croton several species for which neuroprotective activity on the nervous system was evidenced. Also, compounds isolated from Croton species exert a wide range of biological activities such as anti-inflammatory, antifungal activity, neurite growth-promoting activities (Xu et al., 2002) as well as astrocyte and microglial activation and differentiation (Costa et al., 2012). Croton blanchetianus Baill. (CB), is a plant from the Brazilian semi-arid and has botanical synonyms like Croton sonderianus Müll. Arg. and Croton alagoensis Müll. Arg. (Angélico et al., 2011; de Lima \& Pirani, 2008; I. M. M. Oliveira et al., 2015).

Taking into account the neuroscience necessity to understand and provide therapeutic strategies that enable central axonal regeneration and considering the potential neuroprotective effect of $\mathrm{CB}$ essential oil, this study aims to evaluate their effects on the CNS cell plasticity.

\section{Methodology}

This is quantitative and experimental study carried out under controlled conditions (Sampieri et al., 2013).

\subsection{Plant material}

Air-dried plants of cultivated Croton blanchetianus were obtained from Universidade do Estado do Rio Grande do Norte (UERN). Essential oil was obtained by hydrodestilation with clevenger apparatus. Then, $750 \mathrm{ml}$ of distilled water (1:10, w/v) was added. Extraction was performed for three hours. Next, the essential oil was collected and placed into a vial with anhydrous sodium sulfate to remove any water. Then, vials were stored at $4^{\circ} \mathrm{C}$ for later analysis. The characterization of a sample of $C$. blanchetianus essential oil using gas chromatography-mass spectrometry revealed a high concentration of azulene, caryophyllene and $\beta$-elemene. For the purpose of study, $0.1 \mu \mathrm{L}$ of the essential oil was diluted in $100 \mu \mathrm{L}$ of 
phosphate buffered saline (PBS) 0,2 M. This solution has the concentration $0.01 \mu \mathrm{L}$ C. blanchetianus essential oil.

\subsection{Animals}

Male Wistar rats of an approximate age of 45 days and neonates aged 2 days were used under the approval of the Ethics Committee on Animal Experimentation from UERN, Protocol number 006/17, in accordance with the ethical principles adopted by the Brazilian Society of Laboratory Animal Science and according to law number 11,794, the Arouca law, of the Ministry of Science, Technology and Innovation. After the breast-feeding period, rats were kept in a UERN's vivarium in separate cages with adequate housing conditions with free access to food and water until they were of appropriate weight and age.

\subsection{DMEM Conditioning for Sciatic Nerve Explants}

Under laminar flow, 60-mm (P60) culture plates with lids were prepared with $5 \mathrm{~mL}$ of Leibovitz-15 medium (L-15: Gibco, USA). Animals were anesthetized (Ketamine and Xylazine of Agener Union 10\%) and subjected to extraction of the sciatic nerve after the dorsal region was shaved and for local asepsis was used $2 \%$ chlorhexidine. Surgical incisions were made in the posterior region, and the sciatic nerve was removed and placed in P60 with L-15 medium under aseptic surgical conditions with the aid of micro devices (scissors, forceps and retractors). All the excess tissues (muscle, fat, and blood vessels) attached to the nerves were removed under magnification by a SZ61 stereomicroscope (Olympus, Japan). Next, the epineurium of the nerves was removed under magnification via microsurgical techniques. The dissected nerves were segmented into $2 \mathrm{~mm}$ length explants. Under laminar flow, the nerve fragments were placed in $60-\mathrm{mm}$ plates with $1.5 \mathrm{~mL}$ of low Knockout Dulbecco's modified Eagle's medium (DMEM) (Gibco, USA) plus 10\% foetal bovine serum and 0.1\% gentamicin, with a medium called D-10. Excess medium was removed from the explants so they would not float or submerge. The D-10 medium from these cultures was changed twice per week, and the explants were transferred to a new plate with fresh medium once per week. The medium was changed once and then disposed. This procedure allowed an adequate nutrient supply to the explants and an analysis of their reactivity (Figure 1).

Figure 1. Initial cellular migration by the sciatic nerve explants.

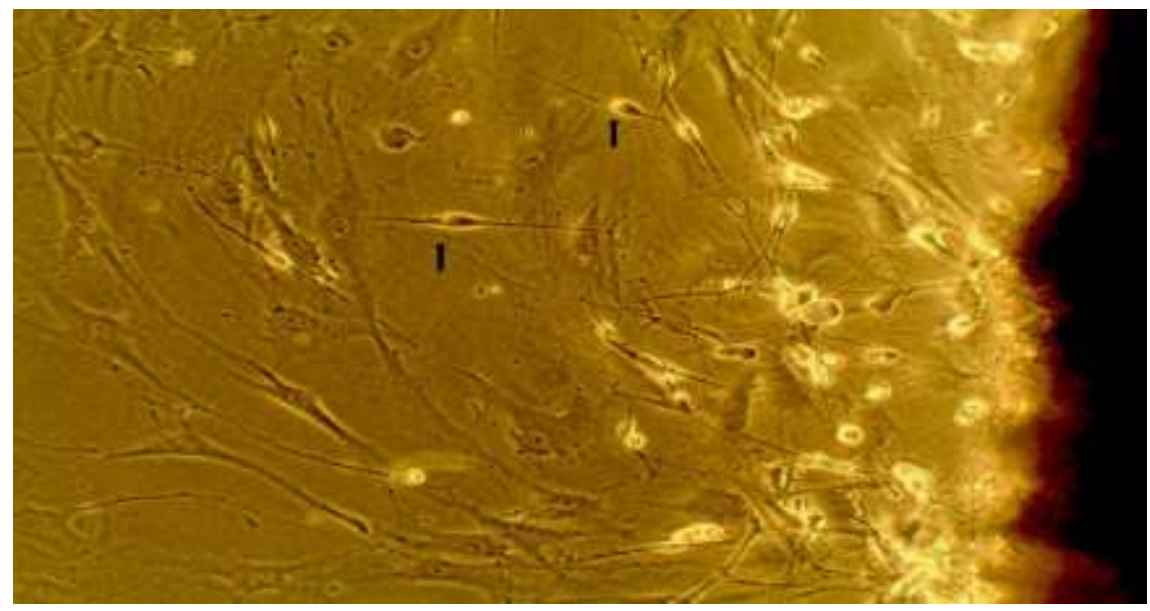

Source: Authors.

The Figure 1 indicates that the cells migrated from their explants, making possible the active compounds production and its exocytosis in culture medium, acting as an extracellular matrix. In this way it was possible collect the conditioned medium for SC neurons treatment. At this stage, SNCM (100 $\mu 1 /$ plate) was collected for inoculation into the SC cell culture. 


\subsection{Isolation and SC Cell Culture}

The animals were killed with an anaesthetic overdose of isoflurane inhalation (Isoforine ${ }^{\circledR}$ ) (Cristália, Brasil), and then dissected under aseptic conditions for the SC removal. After the removal, the explants were held in a conical tube with L-15. Under laminar flow, 60-mm culture plates were prepared with D-10 cell culture medium. Unattached cells and residual non adherent red blood cells were removed after 24 hours by PBS wash. After 1 week in treatment the cells were resuspended from the plates with trypsin-EDTA and subjected to the 3 cycles of centrifugation with washes. Then, the SC cells were plated in 24well plates $\left(1 \times 10^{6}\right.$ cells/well $)$ and were observed over 96 hours. With this procedure, it was possible to assess the adhesion and proliferation of SC cells in the following groups: Group 1: SC cells + D-10 medium; group 2: SC cells + SNCM; group 3: SC cells $+\mathrm{SNCM}+\mathrm{CB}$ essential oil $(0,01 \mu \mathrm{L})$ and group 4: SC cells $+\mathrm{CB}$. The cell count was done using phase microscopy in 9 non overlapping fields at 10x magnification with a CKX41 microscope (Olympus, Japan). The 4 groups photomicrographs were performed after 96 hours.

The cell morphology was observed using phase contrast microscopy at 10x magnification. After cell observation at 96 hours of cultivation, we proceeded with immunocytochemistry for neuronal definition and the cellular morphometric analysis (area and perimeter) was performed.

\subsection{Immunofluorescence Staining}

By day three (96 hours), the cells had adhered to the plates, the medium was removed, and they were washed in two steps of five minutes each in PBS 0.1 M, pH 7.4; the cells were then fixed in paraformaldehyde (PFA) 4\% for thirty minutes and washed again in three baths of PBS (five minutes each). Then, the cells were treated with $0.5 \%$ Triton X-100 (Sigma) for 10 minutes and washed in PBS again. Subsequently, blocking of nonspecific sites was performed for 30 minutes in a PBS 0.1 M solution containing $0.2 \%$ Triton and $1 \%$ cattle serum albumin (CSA).

Plates were incubated for 2 hours at room temperature with anti-mouse Glial fibrillary acidic protein (GFAP) (Sigma, 1:400), anti-mouse GAP-43 (Sigma, 1:2600) and NeuN (Millipore, 1:500). Upon completion of this step, cells were washed in PBS (0.1 M, pH 7.4) for five minutes and incubated for 1 hour with an anti-rabbit or anti-mouse secondary antibody produced in donkey (Jackson, USA) conjugated with AlexaFluor 594 or FITC fluorophore and kept under refrigeration with absence of light. After secondary incubation, cells were washed with PBS for five minutes and immediately examined with a fluorescence microscope (Eclipse E200, Nikon) and then with a second fluorescence microscope (Eclipse Ni, Nikon). Photomicrographs were taken with Moticam 3.0 and 5.0 (Motic) digital cameras at 4x, 10x and 20x magnification in 9 fields in a predetermined sequence on each plate. The presence of fluorescent staining was recorded in SC cells, taking care to examine the subcellular, cytoplasmic, and nuclear compartments.

\subsection{Electronic Scanning Microscopy}

After a period of 96 hours, the samples were fixed to stabilize the form, which consists in the process of preserving the original state of such samples in culture, avoiding to the maximum the introduction of artefacts.

The SC cells from each group were fixed in a $2.5 \%$ glutaraldehyde solution buffered with $0.1 \mathrm{M}$ sodium phosphate $(\mathrm{pH}$ 7.4) and washed in $0.1 \mathrm{M}$ sodium phosphate buffer $(\mathrm{pH} 7,4)$. Post-fixation was then performed on $1 \%$ osmium tetroxide solution buffered with $0.1 \mathrm{M}$ sodium phosphate ( $\mathrm{pH}$ 7.4) for two hours. After post-fixation, the samples underwent three washes in the buffer solution and two washes with only distilled water. Subsequently, the samples were dehydrated in ethanol at different concentrations $(50 \%, 70 \%, 90 \%$, and 100\%). The material was mounted on a Stub sample holder and sputtered gold on the plate for observation in a TESCAN® vega 3 LMU scanning electron microscope. The best representative images were processed. 


\subsection{Statistical Analyses}

Two independents calibrated investigators (kappa $=0.94$ ) the counted cells per field in absolute numbers, using cell cultures of at least 3 different experiments with 10x magnification. The Motic Images Plus 2.0 (Motic) software was used for morphological observation (area in $\mu \mathrm{m}^{2}$ and perimeter in $\mu \mathrm{m}$ ), Image $\mathbf{J}$ software was used for cell counting, and Adobe Photoshop CS6.0 (Adobe) software was used to fix the minimum brightness and contrast of the photomicrographs. The database search was built on the SPSS platform software (Statistical Package for Social Sciences) version 22.0, with a subsequent consistency check of typing. After the final database structure was completed, a descriptive analysis of all data was initially performed. The data were statistically compared by analysis of variance (ANOVA) with Tukey and Bonferroni tests and considered significant when $P<0.05$.

\section{Results}

\subsection{Cellular morphometry analysis}

The cellular morphometry analysis results can be seen in Figures 2 and 3.

Figure 2. Neuronal cells morphometry analysis.

A

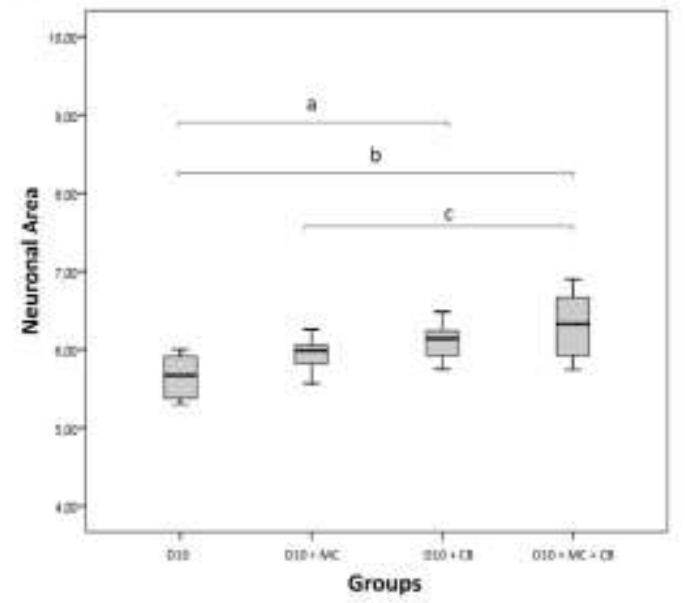

B

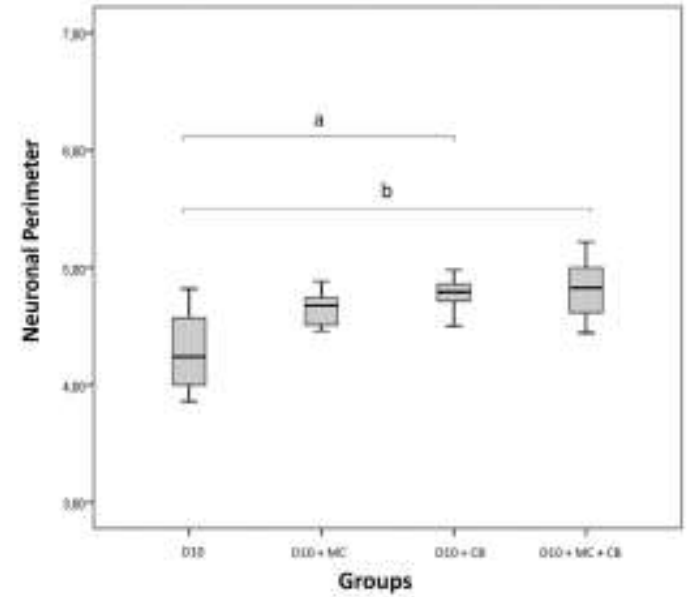

C

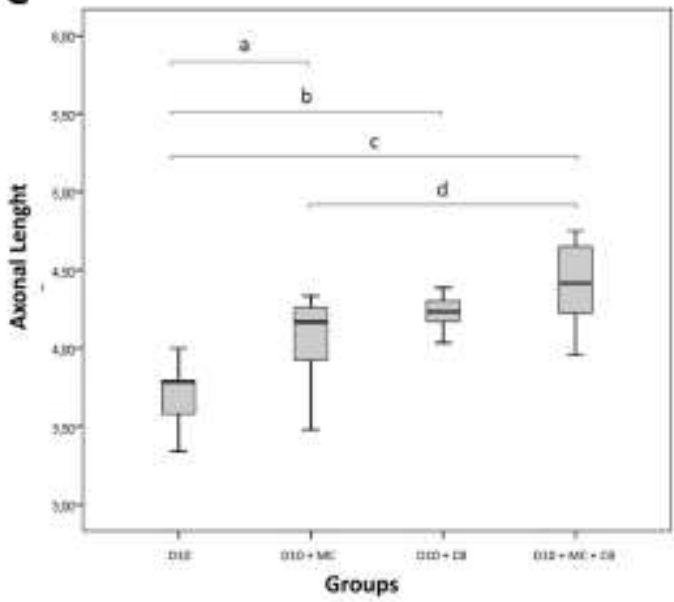

(A) Average area of neuronal cells in the SNCM, CB essential oil and SNCM plus CB essential oil groups. Means \pm S.E.M. Difference in a $(p=0.022)$, b $(p=$ $0.000), c(p=0.019)$, according to ANOVA and pos-test Tukey and Bonferroni. (B) Perimeter of neuronal cells in the SNCM, CB essential oil and SNCM plus CB essential oil groups. Means \pm S.E.M. Difference in a $(p=0.001), \mathrm{b}(p=0.003)$, according to ANOVA and pos-test Tukey and Bonferroni. (C) Axonal length of neuronal cells in the SNCM and SNCM plus CB essential oil groups. Means \pm S.E.M. Difference in a $(p=0.001), \mathrm{b}(p=0.000), \mathrm{c}(p=0.000), \mathrm{d}(p=$ 0.001), according to ANOVA and pos-test Tukey and Bonferroni. Source: Authors. 
Figure 3. Glial cells morphometry analysis.

A

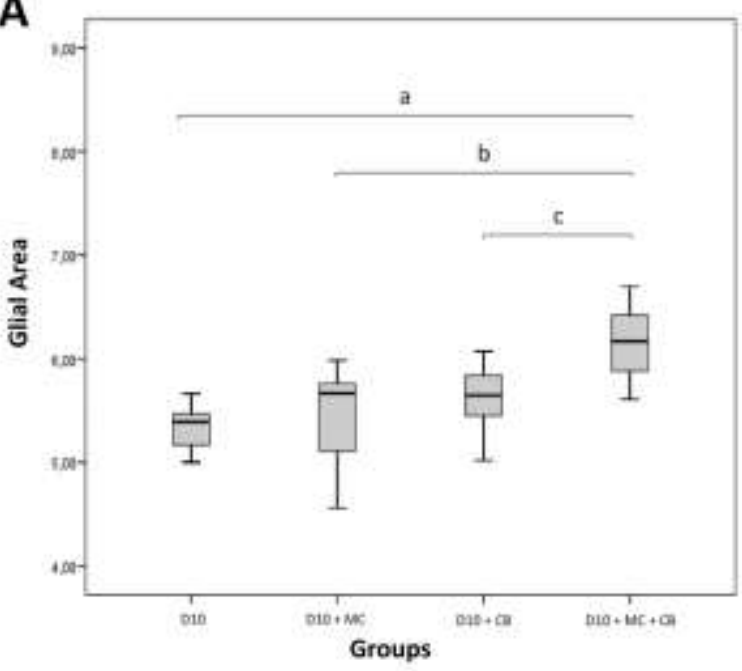

B

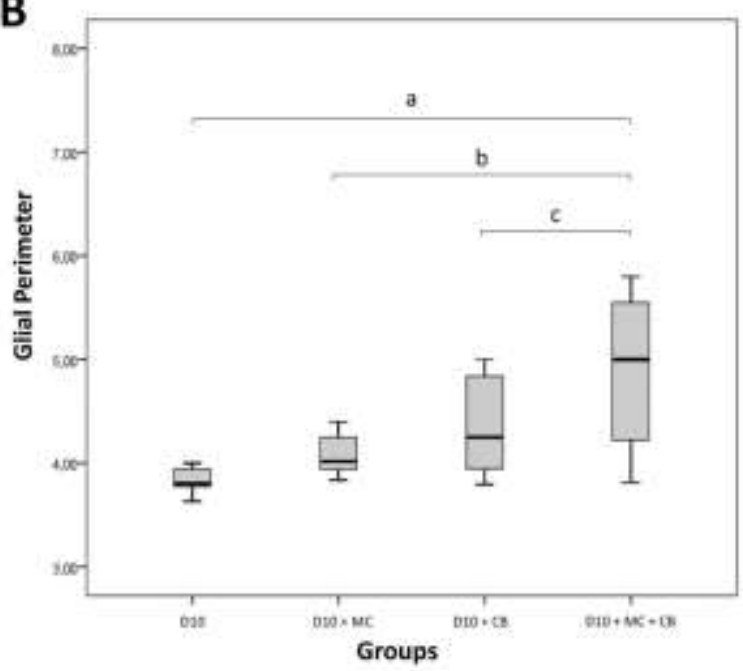

(A) Average area of glial cells in the SNCM and SNCM plus CB essential oil groups. Means \pm S.E.M. Difference in a $(p=0.001), b(p=0.000), c(p=0.001)$, according to ANOVA and pos-test Tukey and Bonferroni. (B) Perimeter of glial cells in the SNCM and SNCM plus CB essential oil groups. Means \pm S.E.M. Difference in $\mathrm{a}(\mathrm{p}=0.000), \mathrm{b}(\mathrm{p}=0.005), \mathrm{c}(\mathrm{p}=0.002)$, according to ANOVA and pos-test Tukey and Bonferroni. Source: Authors.

When comparing the mean areas of neuronal and glial cells observed at 96 hours, the Figure 2 graphic A shows that group 3 was superior to group $1(p \leq 0.01)$, group 4 was superior to groups 1 and $2(p \leq 0.01)$ for neuronal cells. It reveals evident trophic development in the groups that received CB essential oil, when compared to the control group (D10) and in the group that received SNCM in the presence of CB essential oil, when compared to the group with SNCM (D10 + MC). For glial cells, Figure 3 graphic A shows group 3 was superior to group $4(p=0,001)$ and group 4 was superior to groups 1,2 and 3 ( $p \leq$ 0,001). It indicates evident trophic development in the group that received SNCM in the presence of CB essential oil, when compared to the control group (D10), group that received SNCM and group that received only CB essential oil.

When comparing the mean perimeter of neuronal and glial cells observed at 96 hours, Figure 2 graphic B shows that groups 3 and 4 were superior to group $1(p \leq 0,001)$ for neuronal cells. There is evident trophic development in the group that received CB essential oil, when compared to the control group (D10). For glial cells, in the Figure 3 graphic B group 3 was superior to group 4 ( $p=0,001)$ and group 4 was superior to groups 2 and 3 ( $p \leq 0,001)$. Trophic development is evident in the group that received SNCM in the presence of CB essential oil, when compared to the control group (D10), group that received SNCM and group that received only CB essential oil.

For the mean axonal length of neuronal cells observed at 96 hours, Figure 2 graphic $\mathrm{C}$ displays that groups 2,3 and 4 were superior to group $1(p \leq 0,001)$, group 4 was superior to group $2(p=0,001)$. This indicates evident trophic development in the group that received CB essential oil, when compared to the control group (D10) and in the group that received SNCM in the presence of CB essential oil, when compared to the group with SNCM (D10 + MC).

\subsection{Immunofluorescence Staining}

The Immunofluorescence staining photomicrographs are grouped in the Figure 4. 
Figure 4. Immunofluorescence staining photomicrographs shows SNCM-treated cells, CB essential oil-treated cells and SNCM + CB essential oil-treated cells.
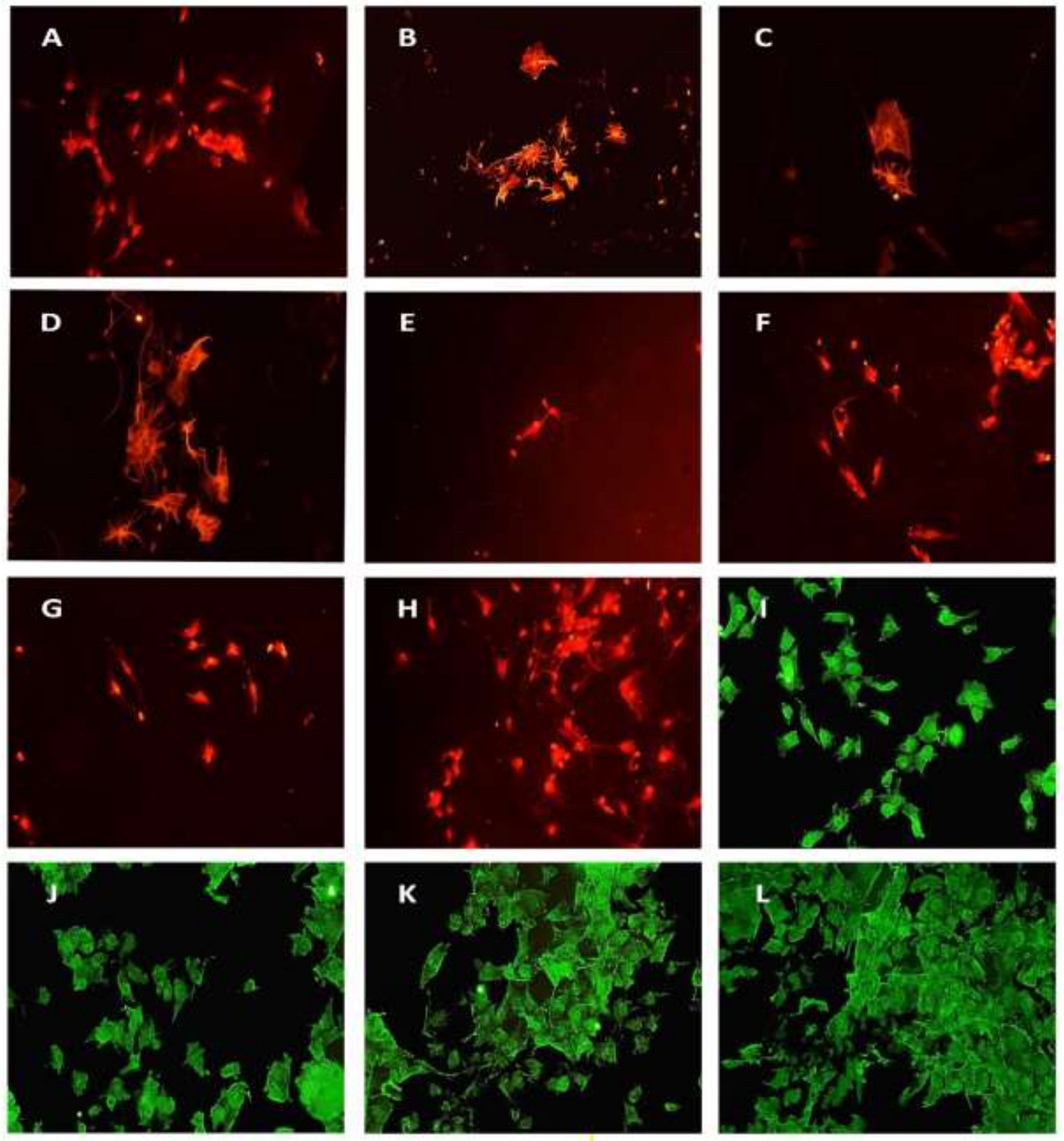

Source: Authors.

The groups treated with SNCM in the presence of CB essential oil showed more evident immunoreactivity for GFAP (Fig. 4A, 4B, 4C and 4D), GAP-43 (Fig 4E, 4F, 4G and 4H) and NeuN (Fig. 4I, 4J, 4K, 4L) compared to the other groups. GFAP marking demonstrates cells treated with control group (4A), SNCM (4B), CB essential oil (4C) and cells treated with SNCM + CB essential oil (4D) and demonstrates more reactive astrocytes in groups treated with SNCM and CB essential oil. Those for GAP-43 (4E, 4F, 4G and 4H) demonstrates a higher trophic effect in groups treated with SNCM and SNCM + CB essential oil while for NeuN (4I, 4J, 4K and 4L) demonstrates a higher trophic effect in groups treated with SNCM and SNCM $+\mathrm{CB}$ essential oil. 


\subsection{Electronic Scanning Microscopy}

The plastic and trophic effect on cultured cells was verified in the presence of CB essential oil. Over 96 hours, glial and neuronal cells developed plasticity when compared to the D10 medium as in the Figure 5.

Figure 5. Photomicrographs by scanning electron microscopy.
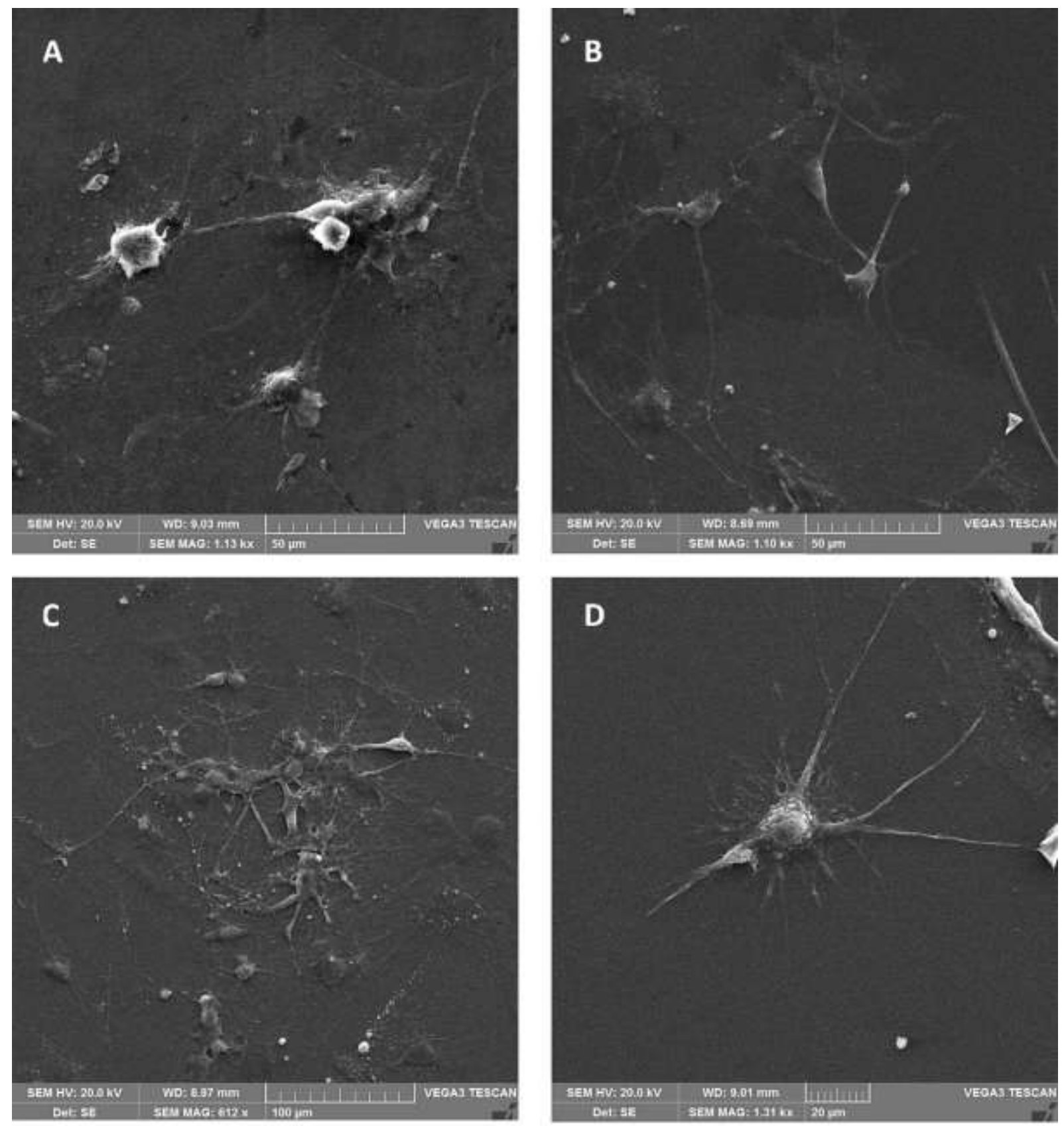

Source: Authors.

The Figure 5 demonstrates the spinal cord cells plasticity, especially cells belonging to the groups treated with $\mathrm{CB}$ essential oil (8A, 8B, 8C and 8D).

\section{Discussion}

This work investigated the plastic behavior of SC glial and neuronal cells after 96 hours of treatment with CB 
essential oil. A conditioned medium with sciatic nerve fragments was also developed, as well as two control groups (D-10 medium and another with the conditioned medium solely, respectively).

Therefore, an experimental medium was created from nerve fragments that simulated an in vivo nerve injury condition where the explants became reactive and naturally secreted factors that enabled a favorable environment for post traumatic nerve regeneration.

Groups treated with CNSM in the presence of CB essential oil showed better results regarding the neuronal and glial area and perimeter and axonal length of SC cells. Furthermore, these results demonstrate that good growth was probably due to the SNCM nutritional contributions, which created a favorable cellular ambient for cell regulation and that promotes growth (Hall, 2001), because Schwann cells retain their biochemical properties during regeneration in the CNS environment (Chen et al., 2005; Guzen et al., 2009, 2012; Schwab, 2002).

CB essential oil probably acted as a neuroprotective and neurotrophic agent, increasing the plastic effect of SC cells. This fact is due to the presence of sesquiterpenes in the CB essential oil, specifically, caryophyllene and $\beta$-elemene, found after gas chromatography coupled to mass spectrometry. Caryophyllene has been reported as neuroprotective in models of cerebral ischemia (Choi et al., 2013), convulsion (Liu et al., 2015), glial cell hypoxia (Guo et al., 2014) and Alzheimer's disease (Cheng et al., 2014). A study by Oliveira (2016) found that the caryophyllene present in the Spiranthera odoratissima essential oil was able to increase BDNF hippocampal levels, the main regulator of synaptic plasticity in learning and memory (Cunha et al., 2010). In another pioneering study by Ferreira (2015), evaluating the caryophyllene effect in three neurodegeneration models in PC-12 cells, it was found that this secondary metabolite, besides inducing cell differentiation, also induced the formation of longer neurites. Wang and Heinbockel (2018), studying $\beta$-elemene, an unoxygenated sesquiterpene, concluded that this compound probably promoted neurite growth in vivo and in vitro, suggesting that $\beta$-elemene may be used as a new treatment strategy for patients with SCI.

The immunofluorescence staining showed that the groups containing CB essential oil had cellular markings for GAP43 and NeuN. Increased GAP-43 expression after injury indicates that the axon is in a regenerative process. Some reports in the literature relate the action of sesquiterpenes in extracts and essential oils with increased GAP-43 expression. Wang and Heinbockel (2018) found that $\beta$-elemene significantly up regulated the level of GAP-43. According to Mullen et al. (1992) and Casella et al. (2004) the high expression and concentration of NeuN indicates a differentiation state or neuronal activity. Therefore, it is evident that there may be some other active compound responsible for the neurotrophic action of CB essential oil. Since essential oils are a phytocomplex, several components present in its constitution may be responsible for its final action (D. R. de Oliveira, 2016).

\section{Conclusion}

This paper opens interesting perspectives for understanding the role of essential oils as stimulants in the nervous cellular environment and their interaction with a nutritive environment within this environment, inducing morphological changes and enabling the plasticity of ME cells in a neuronal and glial lineage. It is concluded that CB essential oil probably has neuroprotective and neurotrophic activity in SC cells. Further research should be done to clarify phytoconstituent's mechanism of action in the essential oil since it is unknown and deepen the use of plant-derived natural products in neuroscience studies. This work contributes with knowledge in the search for better therapy techniques applied in diseases and trauma in the nervous system. 


\section{Acknowledgments}

This study was financed in part by the Coordenação de Aperfeiçoamento de Pessoal de Nível Superior - Brasil (CAPES) - Finance Code 001. This study was supported by funding from the Conselho Nacional de Desenvolvimento Científico e Tecnológico (CNPq).

\section{References}

Angélico, E. C., Costa, J. G., Rodrigues, O. G., Lima, E. Q., \& Medeiros, R. S. (2011). Composição química do óleo essencial das folhas de Croton blanchetianus (Baill): Resultados preliminares. Revista de Biologia e Farmácia, 5(2), 44-49.

Barbosa, L., Filomeno, C., \& Teixeira, R. (2016). Chemical variability and biological activities of Eucalyptus spp. Essential oils. Molecules, 21 (12), 1671. https://dx.doi.org/10.3390\%2Fmolecules21121671

Bergman, R. (2000). Acute spinal cord trauma: Mechanisms and clinical syndromes-Secondary injury and clinical syndromes can aggravate the already critical nature of primary spinal cord trauma. Understanding the spinal. Veterinary Medicine, 95(11), 846-850.

Bizzo, H. R., Hovell, A. M. C., \& Rezende, C. M. (2009). Brazilian essential oils: General view, developments and perspectives. Quimica Nova, 32(3), 588594. http://dx.doi.org/10.1590/S0100-40422009000300005

Casella, G. T., Bunge, M. B., \& Wood, P. M. (2004). Improved immunocytochemical identification of neural, endothelial, and inflammatory cell types in paraffin-embedded injured adult rat spinal cord. Journal of neuroscience methods, 139(1), 1-11. https://doi.org/10.1016/j.jneumeth.2004.04.008

Cemil, B., Topuz, K., Demircan, M. N., Kurt, G., Tun, K., Kutlay, M., Ipcioglu, O., \& Kucukodaci, Z. (2010). Curcumin improves early functional results after experimental spinal cord injury. Acta neurochirurgica, 152(9), 1583-1590. https://doi.org/10.1007/s00701-010-0702-x

Chariker, J. H., Gomes, C., Brabazon, F., Harman, K. A., Ohri, S. S., Magnuson, D. S., Whittemore, S. R., Petruska, J. C., \& Rouchka, E. C. (2019). Transcriptome of dorsal root ganglia caudal to a spinal cord injury with modulated behavioral activity. Scientific data, 6(1), 83 . https://doi.org/10.1038/s41597-019-0088-4

Chen, Y. Y., McDonald, D., Cheng, C., Magnowski, B., Durand, J., \& Zochodne, D. W. (2005). Axon and Schwann cell partnership during nerve regrowth. Journal of Neuropathology \& Experimental Neurology, 64(7), 613-622. https://doi.org/10.1097/01.jnen.0000171650.94341.46

Cheng, Y., Dong, Z., \& Liu, S. (2014). $\beta$-Caryophyllene ameliorates the Alzheimer-like phenotype in APP/PS1 Mice through CB2 receptor activation and the PPAR $\gamma$ pathway. Pharmacology, 94(1-2), 1-12. https://doi.org/10.1159/000362689

Choi, I.-Y., Ju, C., Anthony Jalin, A. M. A., Lee, D. I., Prather, P. L., \& Kim, W.-K. (2013). Activation of cannabinoid CB2 receptor-mediated AMPK/CREB pathway reduces cerebral ischemic injury. The American Journal of Pathology, 182(3), 928-939. https://doi.org/10.1016/j.ajpath.2012.11.024

Costa, A. P., Tramontina, A. C., Biasibetti, R., Batassini, C., Lopes, M. W., Wartchow, K. M., Bernardi, C., Tortorelli, L. S., Leal, R. B., \& Gonçalves, C.-A. (2012). Neuroglial alterations in rats submitted to the okadaic acid-induced model of dementia. Behavioural brain research, $226(2), 420-427$. https://doi.org/10.1016/j.bbr.2011.09.035

Cunha, C., Brambilla, R., \& Thomas, K. L. (2010). A simple role for BDNF in learning and memory? Frontiers in molecular neuroscience, 3, 1. https://doi.org/10.3389/neuro.02.001.2010

de Lima, L. R., \& Pirani, J. R. (2008). Revisão taxonômica de Croton sect. Lamprocroton (Müll. Arg.) Pax (Euphorbiaceae ss). Biota Neotropica, 8(2), 177231. http://dx.doi.org/10.1590/S1676-06032008000200018

Dumont, R. J., Okonkwo, D. O., Verma, S., Hurlbert, R. J., Boulos, P. T., Ellegala, D. B., \& Dumont, A. S. (2001). Acute spinal cord injury, part I: Pathophysiologic mechanisms. Clinical neuropharmacology, 24(5), 254-264. https://doi.org/10.1097/00002826-200109000-00002

Elufioye, T. O., Obuotor, E. M., Sennuga, A. T., Agbedahunsi, J. M., \& Adesanya, S. A. (2010). Acetylcholinesterase and butyrylcholinesterase inhibitory activity of some selected Nigerian medicinal plants. Revista Brasileira de Farmacognosia, 20(4), 472-477. http://dx.doi.org/10.1590/S0102$695 \times 2010000400002$

Ferreira, D. A. S. (2015). Avaliação do efeito protetor do beta-cariofileno em modelos celulares de doenças neurodegenerativas [Thesis, Universidade de São Paulo]. https://doi.org/10.11606/T.60.2015.tde-17042015-093013

Guo, K., Mou, X., Huang, J., Xiong, N., \& Li, H. (2014). Trans-caryophyllene suppresses hypoxia-induced neuroinflammatory responses by inhibiting NF- $\mathrm{B}$ activation in microglia. Journal of Molecular Neuroscience, 54(1), 41-48. https://doi.org/10.1007/s12031-014-0243-5

Guzen, F. P., de Almeida Leme, R. J., de Andrade, M. S. R., \& Chadi, G. (2009). Glial cell line-derived neurotrophic factor added to a sciatic nerve fragment grafted in a spinal cord gap ameliorates motor impairments in rats and increases local axonal growth. Restorative neurology and neuroscience, 27(1), 1-16. https://doi.org/10.3233/RNN-2009-0454

Guzen, F. P., Soares, J. G., de Freitas, L. M., Cavalcanti, J. R. L. de P., Oliveira, F. G., Araújo, J. F., Cavalcante, J. de S., Cavalcante, J. C., Nascimento Jr, E. S. do, \& de Oliveira Costa, M. S. M. (2012). Sciatic nerve grafting and inoculation of FGF-2 promotes improvement of motor behavior and fiber regrowth in rats with spinal cord transection. Restorative neurology and neuroscience, 30(3), 265-275. https://doi.org/10.3233/RNN-2012-110184

Hall, S. (2001). Nerve repair: A neurobiologist's view. The Journal of Hand Surgery: British \& European Volume, 26(2), 129-136. https://doi.org/10.1054/jhsb.2000.0497 
Houle, S. K., Grindrod, K. A., Chatterley, T., \& Tsuyuki, R. T. (2013). Publicly funded remuneration for the administration of injections by pharmacists: An international review. Canadian Pharmacists Journal/Revue des Pharmaciens du Canada, 146(6), 353-364. https://doi.org/10.1177/1715163513506369

Huang, W. L., King, V. R., Curran, O. E., Dyall, S. C., Ward, R. E., Lal, N., Priestley, J. V., \& Michael-Titus, A. T. (2007). A combination of intravenous and dietary docosahexaenoic acid significantly improves outcome after spinal cord injury. Brain, 130(11), 3004-3019. https://doi.org/10.1093/brain/awm223

Lee, Y.-L., Wu, Y., Tsang, H. W., Leung, A. Y., \& Cheung, W. M. (2011). A systematic review on the anxiolytic effects of aromatherapy in people with anxiety symptoms. The Journal of Alternative and Complementary Medicine, 17(2), 101-108. https://doi.org/10.1089/acm.2009.0277

Lin, M.-S., Sun, Y.-Y., Chiu, W.-T., Hung, C.-C., Chang, C.-Y., Shie, F.-S., Tsai, S.-H., Lin, J.-W., Hung, K.-S., \& Lee, Y.-H. (2011). Curcumin attenuates the expression and secretion of RANTES after spinal cord injury in vivo and lipopolysaccharide-induced astrocyte reactivation in vitro. Journal of neurotrauma, 28(7), 1259-1269. https://doi.org/10.1089/neu.2011.1768

Liu, H., Song, Z., Liao, D., Zhang, T., Liu, F., Zhuang, K., Luo, K., \& Yang, L. (2015). Neuroprotective effects of trans-caryophyllene against kainic acid induced seizure activity and oxidative stress in mice. Neurochemical research, 40(1), 118-123. https://doi.org/10.1007/s11064-014-1474-0

Marcos, A. B. W., Forner, S., Martini, A. C., Patrício, E. S., Clarke, J. R., Costa, R., Felix-Alves, J., Vieira, V. J., de Andrade, E. L., \& Mazzuco, T. L. (2016). Temporal and regional expression of glucose-dependent insulinotropic peptide and its receptor in spinal cord injured rats. Journal of neurotrauma, 33(3), 261268. https://doi.org/10.1089/neu.2015.3877

Mothe, A. J., \& Tator, C. H. (2012). Advances in stem cell therapy for spinal cord injury. The Journal of clinical investigation, 122(11), 3824-3834. https://doi.org/10.1172/JCI64124

Mullen, R. J., Buck, C. R., \& Smith, A. M. (1992). NeuN, a neuronal specific nuclear protein in vertebrates. Development, 116(1), $201-211$.

Oliveira, D. R. de. (2016). Avaliação da atividade tipo antidepressiva do óleo essencial das folhas de Spiranthera odoratissima A. St.-Hil. E de seu componente majoritário, $\beta$-cariofileno.

Oliveira, I. M. M., Santos, H. S., Sena, D. M., Cruz, B. G., Teixeira, A. M. R., Freire, P. T. C., Braz-Filho, R., Sousa, J. W., Albuquerque, M. R. J. R., Bandeira, P. N., Bernardino, A. C. S. S., Gusmão, G. O. M., \& Bento, R. R. F. (2015). Vibrational spectra and DFT calculations of sonderianin diterpene. Journal of Molecular Structure, 1099, 226-231. https://doi.org/10.1016/j.molstruc.2015.06.049

Ormond, D. R., Shannon, C., Oppenheim, J., Zeman, R., Das, K., Murali, R., \& Jhanwar-Uniyal, M. (2014). Stem cell therapy and curcumin synergistically enhance recovery from spinal cord injury. PLoS One, 9(2), e88916. https://doi.org/10.1371/journal.pone.0088916

Ren, Y., \& Young, W. (2013). Managing inflammation after spinal cord injury through manipulation of macrophage function. Neural plasticity, 2013. https://doi.org/10.1155/2013/945034

Sampieri, R. H., Collado, C. F., \& Lucio, M. D. P. B. (2013). Metodologia de Pesquisa (5ª ed.). McGraw-Hill.

Schwab, M. E. (2002). Repairing the injured spinal cord. Science, 295(5557), 1029-1031. https://doi.org/10.1126/science.1067840

Souza, S. A. M., Meira, M. R., Figueiredo, L. D., \& Martins, E. R. (2010). Óleos essenciais: Aspectos econômicos e sustentáveis. Enciclopédia Biosfera, $6(10), 1-11$.

Tankam, J. M., \& Ito, M. (2013). Inhalation of the essential oil of Piper guineense from Cameroon shows sedative and anxiolytic-like effects in mice. Biological and Pharmaceutical Bulletin, 36(10), 1608-1614. https://doi.org/10.1248/bpb.b13-00491

Varma, A. K., Das, A., Wallace, G., Barry, J., Vertegel, A. A., Ray, S. K., \& Banik, N. L. (2013). Spinal cord injury: A review of current therapy, future treatments, and basic science frontiers. Neurochemical research, 38(5), 895-905. https://doi.org/10.1007/s11064-013-0991-6

Wang, Z.-J., \& Heinbockel, T. (2018). Essential oils and their constituents targeting the gabaergic system and sodium channels as treatment of neurological diseases. Molecules, 23(5), 1061. https://doi.org/10.3390/molecules23051061

Xu, G.-P., Dave, K. R., Vivero, R., Schmidt-Kastner, R., Sick, T. J., \& Pérez-Pinzón, M. A. (2002). Improvement in neuronal survival after ischemic preconditioning in hippocampal slice cultures. Brain research, 952(2), 153-158. https://doi.org/10.1016/S0006-8993(02)02988-8 